Mladen R. Perić,

Modern Business School, Belgrade ${ }^{1}$

Alpar Lošonc

University of Novi Sad

Faculty of Technical Sciences
SCIENTIFIC REVIEW ARTICLE doi:10.5937/ekonomika1802085P

Received: December: 18, 2018 Accepted: March, 05, 2018

\title{
TRANSFORMATION OF IVAN STOJANOVIĆ'S THOUGHT: BEFORE AND AFTER YUGOSLAVIAN AND SERBIAN TRANSITION
}

\begin{abstract}
As the title of this paper implies, we will analyze transformation and evolution of Ivan Stojanović's thought. The goal will be to juxstapose his ideas and approaches before and after transition in Yugoslavia and Serbia. By (re)reading his books and papers, we came to conclusion that he underwent transformation in attitude towards market, state, socialism, capitalism, privatization, transition, financial markets, etc., along the lines of prevailing intelectual current of that times, but, due to his theoretical sophistication, he never became market fundamentalist.
\end{abstract}

Key words: Ivan Stojanović, market, state, transition, socialism, self-governed socialism, privatization, neoliberal model, market capitalisation.

JEL classification: B2, B24, P20.

\section{ТРАНСФОРМАЦИЈА МИСЛИ ИВАНА СТОЈАНОВИАЋА: ПРЕ И ПОСЛЕ ЈУГОСЛОВЕНСКЕ И СРПСКЕ ТРАНЗИЦИЈЕ}

\section{Апстракт}

Како назив овог рада имплицира, анализирамо трансформащију и еволуиију мисли Ивана Стојановића. Циљ ће бити успостављање његових идеја и приступа пре и после транзиције у Југославији и Србији. Читајући његове књиге и радове, дошли смо до закључка да је прешао у однос према тржишту, држави, сочијализму, капитализму, приватизацији, транзицији, финансијским тржиштима итд. У складу са превладавајућом интелектуалном струјом тог времена, али, због своје теоријске софистицираности, никада није постао тржишни фундаменталиста.

Кључне речи: Иван Стојановић, тржиште, држава, транзиција, сочијализам, самоуправни сочијализам, приватизација, неолиберални модел, тржишна капитализащија.

\footnotetext{
${ }^{1}$ mladen.peric@mbs.edu.rs
} 


\section{Introduction}

A significant part of the work of Ivan Stojanović focuses on the relationship between socialism and market. It can be said that the same topic represents the backbone of his interest. In all of his works, this topic appears to be decisive before the implosion of socialism. Stojanović practices his analytical and synthetic theoretical effects of the given problem. Accordingly, his important books are related to the analysis of complex and contradictory differences between socialism and market. Therefore, apart from other things, we should mention his comprehensive work Socialism and the Market (Stojanović, 1988), chrestomathy, with detailed comments, Neomarxism and Economics (Stojanović 1987), or we can include a critical book written in coauthorship: Who connects workers with false ties (Pavlović and Stojanović, 1984).

As we know, the issue of relation between socialism and the market is paradigmatically determined by the discussion of the "socialist calculation debate" that began in the 1920s and continued in the thirties. However, the critique of socialism has not begun with this discussion (e.g. the representative of German Historical School, Albert Schäffle, began the criticism much earlier), but the mentioned debate is considered to be even one of the most important in the history of economic theory. Different discussions were written about it, different assessments were made, so the discussion limits and the participants' deficits were thematized (more recently, O'Neill 1996, Hodgson, 2016). It is not our intention here to evoke the sequences of the discussion, but we only plan to position Stojanović's theoretical aspirations about socialism and the market.

\section{Stojanović's Thought Before Serbian Transition}

Is rational economic calculation possible in socialism? Is market socialism possible? What is the scope of rational administration in managing the economic flows? Can market mechanisms that coordinate decentralized economic activities be simulated in socialism? Is socialism the expression of an undeniable truth in management in relation to the effects of the market?

We mentioned some of the typical questions that arose in this debate. On the one hand, there are "leftist positivists" (Düppe) such as Oskar Lange who thematized socialism from the perspective of general equilibrium. On the other hand, there are Austrian economists, such as Ludwig von Mises or Friedrich Hayek, who expressed doubts about equilibrium as well as about any kind of social engineering. However, the socialist calculation debate should not be reduced to political-ideological conflicts. It is equally important to emphasize that another discussion was provoked, and it was a conflict over the scientificity of economic reflection. What guarantees the scientificity of economics? Austrian economists were the critics of formalism and deductive use of mathematics within the framework of economics. They believed that extended formalism prevented the possibility of articulating the processual reality of the market. Unlike them, those economists who tended to accept formal-mathematical procedures in the rationalization of economic management, like Lange did, developed another mode of economic reflection as Austrians who criticized every kind of scientism. Can the market be instrumentalized, can the market serve as a tool for non-market goals, for socialism? The point of discussion lies in this question. 
The Austrians did not underestimate socialism. Their indication that the form of science per se directs the attention of an economic theoretician towards socialism (Hayek, 1949) is important for understanding the work of Stojanović. Moreover, it is suggested that socialism can satisfy intellectual needs more than liberalism (Düppe, 2011). If we consider the scope of Stojanović's works, his dispersive reception of different economic and non-economic theories, then we can confirm that he regards socialism as an intellectual problem. Stojanović's books show a wide range of interests; there is always analytical rigor and intellectual virtuosity, that is, the conceptual orientation that leads reflection in different directions and is ready to face the various dilemmas created by the relationship between socialism and the market. His profound knowledge reveals familiarity with numerous socialist and non-socialist economic theories, but he is ready to analyze economic problems in consideration of non-economic theories. If one scrutinizes his books and discussions carefully, s/he can form an impression of him as a theoretician who carefully, non-apologetically accepted non-Marxist reflections on the market and the criticisms of the same theories.

Stojanović accepted the socialist calculation debate. If we wish to interpret his position, then it can be said that in terms of the scientificity of economics, his opinion is between the Austrian rejection of deductive mathematics and left-positivist scientism. His economic discourse implies analytical results and readiness for the reception of mathematical procedures, which separates him from Austrian economists who, in terms of the design concept of the market, had a significant influence on economic discourse, but in terms of the methodological approach, that is, in terms of interpreting mathematics as a methodological instance, their opinions resulted in failure. The Formal Revolution in economics that took place after the World War II overthrew Austrian economists in the heterodox zone, or close to heterodox positions. At the same time, Stojanović is also separated from those economic theoreticians who are lost in mathematical procedures and who are satisfied with technical performances and absorb market issues into empirical laws. It is important to consider that he believes that political economy, that is, the systematic interaction between economics and politics, is inevitable. Stojanović acknowledges technical procedures as legitimate; he does not want to debate their merit, but in his works, they can be set in a broader political and economic context. We should examine the fact that many significant economists regarded certain economic techniques as instrumentally neutral, purified from political horizons: for example, Frank Knight believed that marginal techniques could be applied in both socialism and capitalism, that is, that the economic theory was neutral, Abba Lerner stated that socialism and liberalism would be merged within the framework of welfare economics (Boettke, 2000, 9). It is believed that economics without political elements, that is, as one significant economist said, economic discourse is "parsimonious" (Hirschman, 1984). Stojanović's acceptance of technical and analytical procedures is within his political orientation.

Let us not forget that Stojanović was not only a theoretician-professor, but also a participant in the activities of high political bodies in former Yugoslavia. His position influenced a constant reflection on the problems of theory and practice. Stojanović's work can also be explained based on the constant transition between theory and practice. This means that Stojanović was active during self-managing socialist Yugoslavia which differed from various modes of real-socialism. This implied openness to market coordination and criticism of state intervention which resulted in etatism. Following 
quotation summerizes this stance: "...one of the fundamental problems of the socialist economy [is] the relation of socialism (self-managed socialism) to the laws of commodity (market) economy (Stojanović, 1988, p. 39).

Majority of theoreticians stated that there was a specific self-government-based mode of production with the following elements: a) social ownership, b) self-government, c) commodity-planning mediated base of economizing (Maksimović 1984, p.7). It was believed that it was possible to coordinate planning with the market, that the planning could be understood by taking into account the coordination and rationalization effects of the market (Horvat, 1984, 270). If we analyze the already mentioned book Socialism and the Market, we can see that one of the most important chapters focuses on the relationship between the plan and the market (Stojanović, 1988, p.477-574). However, the status of the market was not defined and was prone to different interpretations: numerous discussions on the meaning of the market in self-managed socialism were held, and economic theoreticians got involved in the arguments concerning the market range. It was believed that certain market models were a necessary part of self-managed socialism; it was well-known that "law of values" and "commodity production" were already present and they could not be eliminated by administrative measures. However, there was no consensus on what was the cause of survival of "commodity production" in socialism.

Many theoreticians approached the categories of socialist political-economy based on the normative reasoning: they analyzed the existing practice based on the planned desirable content of socialism. Stojanović actively participated in these discussions and took a sophisticated position based on accepted theories. His analyses were not characterized by normative projections, but by immanent analyses that had both macroeconomic and microeconomic aspects. He held his opinion about the analyses even in the second half of the 1980s of the 20th century when self-managed socialism had already deeply got into crisis and when an intensified crisis had already projected its final outcome. Stojanović draws our attention to the necessity of avoiding any simplification: unlike others who have only managed to explain the abstract conflict between the norms and reality, he performs the aforementioned analyses that indicate antinomy between the norms and reality. At the same time, he discusses about contradictions, about inevitable stabilization of socialism, although he always tends to combine the ideas of conceptual valuation. Therefore, we may sometimes read these statements based on the conceptual classification: "One of the most important Yugoslavian ideas in socialism is that the revolution is something else than a normal, peaceful life. Nowadays, taking into account the economic situation, we may have too much of a normal, peaceful life" (Pavlović and Stojanović, 1984, p. 15). It is not just a declarative statement. Unlike many theoreticians who believed that the problem of socialism was resolved based on the normative view, except that the example in practice was a bit late, Stojanović was much more cautious: the problem of socialism, especially the economic problem of socialism, was not resolved; there was no predetermined pattern to be achieved. Unlike those economic theoreticians who thought that the problem of socialism had been solved in advance, and it could be imposed normatively to the determined practice, Stojanovic introduced the elements of non-determination. The existing self-managed socialism can only be the second best and it cannot be achieved if we apply the abstract normative principles. 
With regard to the ultimate cause of commodity production in socialism, Stojanović seems to accept the explanation that it is the employment status which is regarded as a cause. In other words, the work does not appear to be primary need but a survival mean, which is contrary to different projections. This fact implies that the work sphere is determined by economic laws on the basis of compulsion to work. Stojanović's indications are critical of market fetishism, but his critical attitude towards those subjects who underestimate the importance of market decentralization becomes prevailing. It was stated that the Yugoslav society started following the wrong path after the Constitution enacted in 1974. The resulting paths prevented the introduction of rational mechanisms of the market, especially the price mechanisms that simultaneously homogenize different goods and realize their quantitative comparison. This way, the role of the price in the planned economy is thematized, and planned and mathematical prices, labor costs, regional differences in prices or "political costs" are analyzed. Price optimization is to be achieved, and mechanisms that comply the respective optimization with the capabilities of a self-managed economy are to be discovered. Stojanović draws attention to the structure of contemporary market, he writes about oligopolies and other organizational forms that he tends to confront with the flows of self-managed economy.

The starting point is clear: "In particular, the market is a mechanism which does not allow the dominance of the non-economic activities over the economic activities, the voluntarism over economic laws" (Stojanović 1988, 50). Stojanović tends to warn about the fact that shrinking market in Yugoslavia led to the hypertrophication of bureaucratic procedures (called "bureaucratic dogmatism"), intensification of the irrational administration: if there is no market, then it comes to "naturalization" of economy with the loss of motivation for rational economic activity. Stojanović strongly criticizes theoreticians who, with regard to humanism, are constantly suspicious of the market and cannot distinguish between "goods produced by labor" and "capital goods". Humanists who are filled with fear for reification of people suddenly end up in the apotheosis of the state. He also criticizes economic theoreticians who do not want to admit that the means of production are not just "material conditions for production" but that they also have their value. Stojanović criticizes the fetishization of price negotiations and the agreements that are imposed by economic laws. He believes it was illusory of the former Yugoslavia to attempt to overcome the disintegrative tendencies that were rapidly increased in the 1980s through consensus of political wills. He criticizes illusions about "non-property" that were widespread in former Yugoslavia and claims that property cannot be purified from economic significance.

Therefore, Stojanovićs position was not disputable: it supported those orientations according to which the market, in spite of the socialist tendencies, was a powerful regulator of economics which met the complex needs. If we consider the socialist calculation debate, we can say that in Stojanović's opinion, market has simultaneously instrumental and noninstrumental role. Its instrumental role is based on the fact that it can meet certain needs in the transitional period; its non-instrumental role is based on providing elements of democracy for socialism. There are connections between the market and democracy, which additionally gives legitimacy to the market. However, it should be noted that Stojanović was convinced that there was a "socialist commodity production" that could be compared to a capitalist counterpart. Not only does Stojanović use this term, but he also strives to recognize the possibility of "market socialism" through theoretical analyses - in this respect, he could have 
different interlocutors in the group of economists who also advocated for market socialism. He emphasized that the market operated based on laws, but that planning with socialist goals could affect the failures of the market. Stojanović was well aware of the tensions between general planning and allocative market functions. Since the above mentioned socialist calculation debate, the question has been posed as to whether the successful planning is conditioned by having the knowledge of the conditions of efficient production (production possibilities curve) and preferences of consumption - some economists believe that the problem can be solved in a different and more efficient way by total computerization. If this were correct, then the debate could be open in the 21st century. Lange tried to achieve equilibrium based on the logic in Walras' tâtonnement; today, some authors anticipate possible computer algorithms in terms of price adjustment (Jablonowski, 2011, Dore, Kaser, 1984). Naturally, it is still to be analyzed; one possibility is that the same possibilities can be raised within the scope of expanding experimental economics. Stojanović was aware of the planning process as a whole, that is, a plan that had a macroeconomic range but, owing to self-management, it also had its decentralized form. He knew it was not simple to integrate the market into the planning mechanisms and it was clear that it was extremely difficult to integrate the market benefits into the proportions of the plan. However, he did not want to blur the distinction between "socialist commodity production" which goal was to increase the "social use value" and the capitalist commodity production which aim was to "exchange value". He believed that the "law of value" had powerful effects only on the material sphere: in terms of labor, socialism should overcome determinations by commodity-based practices. Stojanović was clear about theoretical choices as well, namely, he also took sides in heated leftist discussions during the 1970s and 1980s. During this period, the attention of the economists was directed to the work of Piero Sraffa and some economists proposed Yugoslavian government to substitute Marx with Sraffa. Stojanović, however, (in the co-authorship) states that the difference lies between the aforementioned theoreticians in assessing the value of goods; Sraffa is focused on the assessment of values based on physical volumes and prices of production. Marx is more complex because he adds the law of value based on labor and opens up the ability to understand the capital as a unity of different determinations.

The crisis that arose in the Yugoslavian society in the 1980s did not make Stojanović change his attitude to the market and socialism, or there are at least no clear signs of it. At the end of the mentioned period, however, there was a collapse of socialism. This caused the change in the opinions of many economists. The market was regarded as a regulator without any competition (Stojanović, 1990), but, as we have already said, not with the Austrian logic of processuality.

\section{0s and Deviation from Socialism}

Although even before the 1990s Ivan Stojanović was promarket oriented, in the 1990s, he significantly abandoned the ideas of socialism and turned to neoliberalism, in accordance with the general trends at the time. ${ }^{2}$ In this regard, the following quote

\footnotetext{
${ }^{2}$ An interesting look at neoliberalism was given by one of the most famous authors of the PostKeynesian school of economic thought, Steve Keen. He both humorously and critically observed that neoliberalism is a introductory neoclassical economics disguised as a political philosophy (Keen,
} 
is illustrative: "The dominant characteristic of progressive economies in the world is that they are primarily based on private property, the freedom to enter into contracts and establish other relationships among enterprises, and to reduce and change the role of the state in the economy. The basic pillar of market economy is private ownership of enterprises, in various aspects, from the individual ownership of individuals over small enterprises to large stock companies. The follow-up pillar is the maximization of profits, as the main of entrepreneurship goal before taking the most efficient resource allocator and regulator of economic processes. " (Stojanović, 2000a).

The preceding quote, therefore, gives a typical neoliberal assessment of how the market in cooperation with private ownership guarantees economic growth and development, while the state should withdraw from the economy and let the economic entities freely contract and partake in economic transactions (the critique of this approach was given in: Lošonc and Perić, 2017). However, we can not lose sight of the historical context in which the previous quote originated. In the 1990s, the ideas of neoliberalism and neoclassical economics (neoclassical synthesis, to be more precise) were popular and they sounded "fresh" to many when the "over-indebted country" in the 1980s according to the criteria of international financial institutions (mostly IMF) ended up in war devastation and international sanctions in the 1990s. Neoliberalism became ideology without ideology, i.e. ideology disguised as objective, scientific, and tehnocratic practical policy making. We appear to accept the proposition that this utopian faith from 1980's describes a neutral force; a kind of biological law, like Darwin's theory of evolution. However, this philosophy arose as a conscious effort from capital aimed at shifting the locus of power from labour to capital. Simply, neoliberalism and its simple and "attractive" postulates were perceived as interesting at a time when the latter only began to impose their hegemony. ${ }^{3}$ We live today in difficult but interesting times of the neoliberal economic model collapse. This model, among other things, is characterized by an affirmative view of the market and critical - not to say the suspicious - view on the state and its institutions. Such an approach has led to its radical outcome in the recommendations for economic policy pursued by the International Monetary Fund and the World Bank since the 1980s. They have imposed privatization, deindustrialization and promotion of the service sector, import dependence, compensation of stagnant and declining worker rentals by increased borrowing, reduction of workers' rights and "relaxation" of labor legislation, credit dependence, etc. on "developing countries".

With a group of contemporaries (of which the most significant representative was Zoran Pjanić), Stojanović belonged to the group of "profitaša" (group of socialist economists who considered profit legitimate goal in socialism), in contrast to "dohodaša" (who considered that self-managing socialism can not recognize profit and other capitalist institutions - only income). Despite emphasizing the advantages of a liberal economy, Stojanović was not a

2017, p. 46). However, if we don't wanna be misunderstood, we do not want to say that Stojanovic's analyzes are at the level of the basic neoclassical economy, on the contrary. Behind his attitudes and approaches there is a good theoretical foundation and professional background (see, for example: Stojanović, 1989). The failings that we will be criticizing hereunder may be attributed to the spirit of the 1990s and neoliberal hegemony, which certainly had a major impact on his work in that period.

${ }^{3}$ Instrumental in achiving this hegemony were neoliberal think thanks. Corporate-funded think tanks have played a central role in promoting free market philosophy onto the policy agenda throughout the world. They have consistently promoted deregulation, privatization, and pro-market reforms. 
market fundamentalist in a sense that he felt that all activities should be subject to market logic, but also respected the virtues of the welfare economy. The following quote reinforces that angle: "Public goods (activities, services) generally (should) function on the basis of quasi market-based solutions, because market laws in these activities often do not provide optimal solutions from the standpoint of the interests of society and welfare economy as a whole. In health, culture, education, etc. supply and demand, as the most important market elements, can not be the main regulators of optimal or equilibrium volumes of production, consumption, prices. Under market conditions these optimums or equilibrium are achieved with the equality of marginal costs and prices (marginal revenues, depending on the competition or monopolization present in the markets). In the case of public goods, however, the stated equality only partially provides the optimum. Companies operating in the public goods sector are most often monopolistic. The market for public goods and services is a specific quasi-market: on the one hand, it provides centralized (monopoly) offer, on the other decentralized demand. Profitability in public sector enterprises does not have same role as in private, stock, cooperative, etc. " (Stojanović, 2000a)

If privatization is subject, Stojanović has an affirmative approach in analyzing this process. The following quotation confirms this: "One of the main questions raised about the process of (re) privatization is: why do these processes come, what are their causes? General arguments that favor privatization relate to: efficiency; economic freedom democracy; reduction of the public (state) deficit; improvement of the means of negotiating and agreement between economic and other social subjects on various issues (economic, social, etc.). "(Stojanović, 2000b) Stojanovic sees privatization as a process that will lead to rise of democratic standards in society through the increase of economic freedom, and as the most progressive economic and political system he offers the so-called people's capitalism. This means that ownership over the means of production should be widespread among the population and through the massive shareholding people will be motivated to save and invest rather than to consume. ${ }^{4}$ To this approach we could address the following criticism: capitalism is based on exploitation, that is, it is the order which, in order to function, requires that most of population (workers) work for the minority (capitalist or employer). By applying the conception of people's capitalism, the opportunity for this exploitation would be reduced, the equity stakes would be dispersed and thereby profitability of investments decreased, which ultimately could lead to a "capital strike" (pressure on cost reduction or even abandonment of investments) and endangering the capitalist order.

"Privatization raises overall economic efficiency, primarily because it eliminates the weaknesses of publicly owned enterprises and also the weaknesses of state interventionism. Namely, the decades-long experience, as the countries of the West and more of those in the East (with socialist socio-economic systems), proves that public property (state, social, "national," nationalized) does not have, at least not sufficiently, incorporated bankruptcy risk (bankruptcy, collapse), precisely because of the state (at the expense of the budget) support to such companies. Likewise, the weakness of publicly owned enterprises is absence, lack of financial sanctions for

\footnotetext{
${ }^{4}$ Radical neoliberal and market fundamentalists criticize people's capitalism and often call it economic populism. The following quotation confirms this: "This [people's capitalism and widespread shareholding] is an absurdity that retains the political power of the ones on the top, whose goal is only to acquire more stocks, which would be the Russian model of tycoonization, or to free itself and collapse, which would be a Serbian model (Popović, 2007).
} 
their bad business decisions, since in most cases these companies are not forced to acquire capital for their business in capital market. (Stojanović, 2000b) We do not need to emphasize that privatization did not bring the desired results both in the domain of increased economic efficiency and the macroeconomic growth and development of Serbia. Due to limited space, we will illustrate this only with decline in employment in enterprises that are privatized in the period from 2002 to 2011 (when the privatization process was the most intensive).

Graph 1. Number of employees in privatized companies in the period from 2002 to 2011 (in thousands)

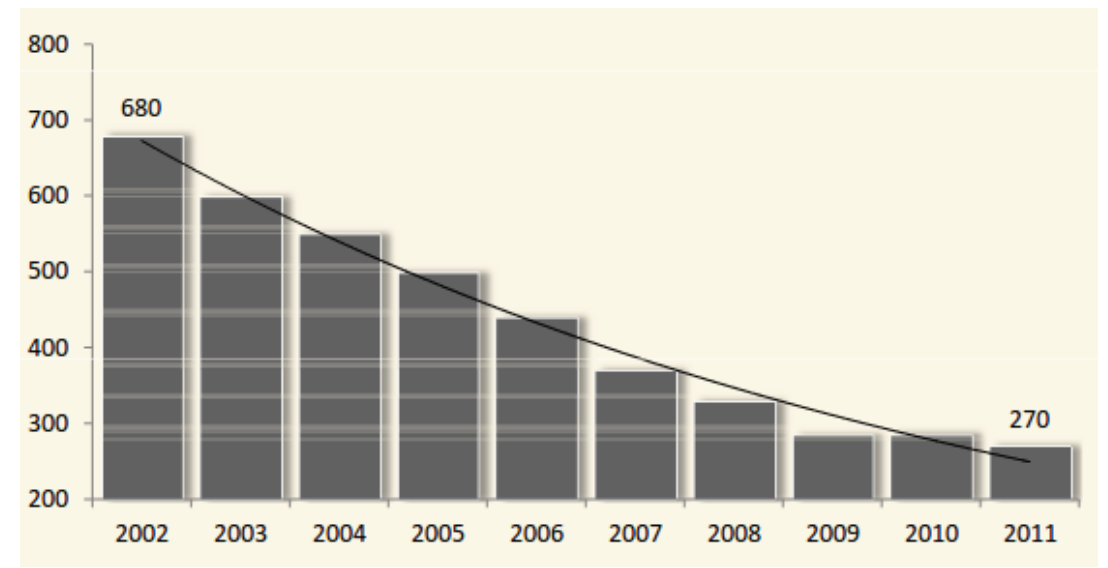

Source: Nikolić (2012).

We can see that the total number of employees in the observed period decreased by about 410,000 , which means that on average about 45,000 jobs per year in the newly privatized companies disappeared. Also, the conducted research confirms that the privatized companies give a modest contribution to the creation of gross added value in Serbia, and privatization has met expectations only in certain areas of the processing industry (Nikolić, 2013). So, privatization has failed to fulfill the promises of the promarket ideologists (Mitrović, 2010).

Stojanović $(1992,1993)$ emphasized in the 1990s the advantages of market institutions such as financial markets (money markets, capital, foreign exchange and futures markets), stock exchanges and integrated markets (the market for goods, services, capital and labor). He argued that there wood be no dynamic economic growth without developed financial markets, while he did not warn of the dangers posed by speculative capital and its instruments (such as financial derivatives, for example). His treatment of market capitalization (value of share capital) is particularly interesting. He argues that developing countries have achieved faster growth in market capitalization and that growth of the later is key factor for economic growth. However, there is also no criticism of the nature of such growth. Namely, the growth of market capitalization can be due to the socalled paper entrepreneurship; that is, mainly financial and accounting measures for raising the value of shares. The most common form is the purchase of company's own shares in the financial markets in order to increase demand and price for the shares. Also, one should not lose sight of the impact of speculative capital and the banking sectors expansive policy of 
lending (the so-called credit bubble). The impact (and correlation) of loans and speculative capital on market capitalization can be seen in the following graphic.

Graph 2. Margin debt compared to the DJIA - correlation 0.945

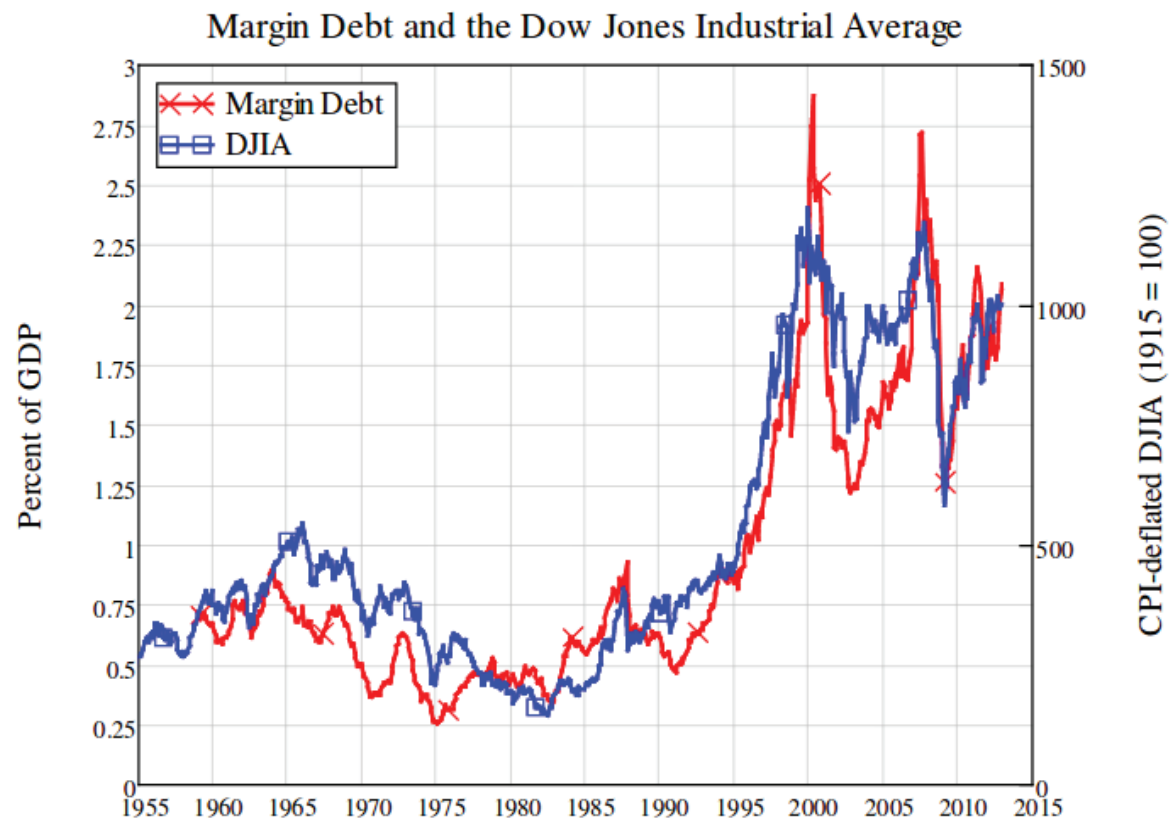

Source: Keen (2013).

The later work of Stojanovic is also characterized by positive treatment of the so-called structural changes and transitional processes in the countries of Southeast Europe and the inevitability of the coexistence of both. "What is particularly important is that transition (from non-market to market-based forms of business) already, almost by definition, means and assumes large structural adjustments and changes in the economy. It is about a kind of so-called feedback loop - no transition (and what it is aimed for raising the overall efficiency of the economy to a higher level, etc.) without structural changes in the economy, and vice versa - the real necessary structural changes in the economy without a transition (again, from non-market to market forms of business, or the creation of everything that means that the economy is really a market economy, and of all aforementioned, it is change of the ownership structure that is especially important)." (Stojanović, 2000b). Without going into the critique of transitional discourse, in the sense that it is resisting the present evaluation (because the results are always displaced into the future and that this process has no end), the transition in Serbia has brought the technological-economic lag for the most of the installed capacities, dominant position for traditional industrial production, a rather dispersive export assortment, which was, to a considerable extent, used to a significant degree in the past to a changing customer base and placed on a limited number of destinations, and this is an aggravating circumstance (Cvijanović, Mihajlović and Simonović, 2009). We can add to this the de- 
industrialization, economic and social stratification of the population, import dependence, over-indebtedness, unfavorable economic structure, etc. (Perić and Lošonc, 2015).

If we look at the largest and privatization that has been proclaimed as one of the greatest successes of economic policy makers since 2000: Sartid by US Steel Company, it is not difficult to carry out the calculation. Sartid (including iron and steel, a new and old, a factory of white sheets, a rolling mill ...) canceled \$ 650 million of credit obligations (denominated in foreign currencies) and transferred it to the state. Sartid was sold for 26 million, which is more than a suspicious transaction, because in this process the state of Serbia has been damaged by more than 2.5 billion dollars. But, that is just the most famous case. An analysis of all countries that have begun transition processes since 1989 have shown that they have not reached the economic growth rates that have been promised and that the expected convergence with developed countries has not occurred (Becker et al., 2010).

\section{Conclusion}

The purpose of this article was to give a brief overview of the work of Ivan Stojanovic before and after the beginning of transition changes in Serbia in the 1990s. The article did not intend to deal with all the topics of Stojanović's interest, because topics are many, and the article is limited. Also, we did not deal with the reception of Stojanovic's work when it was created, but we analyzed and somewhat criticized those ideas in the context of the present situation when the "story of transition became stale", that is, at a time when the promarket and neoliberal economic model did not bring promised results.

As we said, the crisis that affected Yugoslavia in the 1980s did not disrupt Stojanovic in terms of his approaches to market and socialism, but in the 1990s he partially "succumbed" to the neoliberal virus in terms of glorification of market institutions such as the financial market, structural neoliberal reforms, privatization and transition (capitalist restoration). In the article, we gave a brief critique of these attitudes, because we believe that the issues Stojanović was faceing are still meaningful and current, but now we have the advantage of the past time in which these ideas have been shown in practice.

Regardless of neoliberal model shortcomings, we consider that even today, something can be learned from Stojanović's books and articles because the struggle between the economic left and right for discursive power continues today, with the fact that we have to notice that the left is withdrawing.

\section{References}

Becker, T., Daianu, D., Darvas, Z., Gligorov, V., Landesmann, M., Petrović, P., PisaniFerry, J., Rosati, D., Sapir, A. and Weder di Mauro, B. (2010). Whither growth in central and eastern Europe? Policy lessons for an integrated Europe, Bruegel Blueprint Series, Vol. XI. http://bruegel.org/wp-content/uploads/imported/ publications/101124_bp_zd_whither_growth.pdf (last accessed 07.12.2017). 
Boettke, P. (ed.) (2000) Socialism and the Market: The Socialist Calculation Debate Revisited, Vol I-IX. Routledge.

Dore, M. H. I., and M. C. Kaser. (1984). The Millions of Equations Debate: Seventy Years After Barone, Atlantic Economic Journal, 12:3, 30-44.

Düppe, A. (2011). The Making of the Economy: A Phenomenology of Economic Science, Lanham, MD, Lexington Books .

Cvijanović, D., Mihajlović, M. and Simonović, S. (2009), Tranzicija u Srbiji: efekti i ograničenja. Tranzicija, Vol.10, No.21-22.

Hayek, Friedrich A. 1949. "The intellectuals and socialism," The University of Chicago Law Review, reprinted in Huszar (ed.) 1960. The Intellectuals: A Controversial Portrait, Free Press, 371-84.

Hirschman A. (1984) Against Parsimony: Three Easy Ways of Complicating Some Categories of Economic Discourse, The American Economic Review, Vol. 74, No. 2, Papers and Proceedings of the Ninety-Sixth Annual Meeting of the American Economic Association, (May), 89-96.

Horvat, B. (1984) Politička ekonomija socijalizma, Zagreb, CRO: Globus.

Huszar (ed.) (1960). The Intellectuals: A Controversial Portrait. Free Press. 371-84.

Jablonowski, M. (2011). Markets on a (Computer) Chip? New Perspectives on Economic Calculation, M. Jablonowski, Science \& Society, Vol. 75, No. 3, July, 400-418.

Keen, S. (2013). A Bubble So Big We Can't Even See It, Real-World Economics Review, No. 64, pp. 3-10.

Keen, S. (2017). Can We Avoid Another Financial Crisis?. Cambridge, UK: Polity Press.

Lošonc, A. i Perić, R. M. (2017). Tržišne i državne 'marginalije'. Politikon, 17, pp. 7-29.

Maksimović, I. (1984). Politička ekonomija socijalizma, Beograd, YU: Savremena administracija.

Mitrović, Lj. (2010), “The Balkans Between the Neoliberal Utopia of the 'Open Society' and the Realities of the Depended Divided Society of Peripheral Capitalism", Ekonomika, Vol. 56, No. 1, str. 56-70.

Nikolić, I. (2012). Privatizacija u Srbiji: između euforije i razočarenja. Ekonomski institut. Savetovanje Naučnog društva ekonomista Srbije. 5. Maj.

Nikolić, I. (2013). Efekti privatizacije na performanse industrijskih preduzeća u Srbiji. Neobjavljena doktorska disertacija, Ekonomski fakultet Univerziteta u Beograd, Kragujevac, Srbija.

Pavlović, D., Stojanović, I. (1984). Ko radnike povezuje lažnim koncima?, Beograd, YU: Bigz.

Perić, R. M. i Lošonc, A. (2015). Uzroci neefikasnosti mera štednje i imperativ reindustrijalizacije. Kastratović, R. M. i Vučinić, Đ. D. (Redaktori) Menadžment, preduzetništvo $i$ investicije u funkciji privrednog rasta $i$ zapošljavanja, Institut za poslovna istraživanja-MBA, pp. 159-171. 
Popović, D. (2007). Besplatne akcije su velika greška. B92, 16. Novembar http://danica. popovic.ekof.bg.ac.rs/akcije-greska.htm (last accessed 07.12.2017).

Stojanović, I. (1987). Neomarksizam i ekonomija, Beograd, YU: Ekonomika.

Stojanović, I. (1988). Socijalizam i tržište, Beograd, YU: Ekonomika.

Stojanović, I. (1989). Ekonomska teorija i sukob antisocijalizma i antikapitalizma. Ekonomika, No. 319, June-July, pp. 18-29.

Stojanović, I. (1990). Ekonomska teorija i sukob antisocijalizma i antikapitalizma. Ekonomika, No. 323, June-July, pp. 22-40.

Stojanović, I. (1992). Ekonomska politika (re)privatizacije, Ekonomika, No. 327, June-July, pp. 13-21.

Stojanović, I. (1993). Koliko vredi privreda SR Jugoslavije - glavni problemi Jugoslovenske privrede i ekonomske politike. Ekonomski Anali, Ekonomski fakultet u Beogradu, pp. 42-57.

Stojanović, I. (2000a). Uloga tržišta u strukturnim prilagođavanjima Jugoslovenske privrede. Ekonomski anali, Strukturni problemi privrede SR Jugoslavije, Ekonomski fakultet u Beogradu, pp. 39-53.

Stojanović, I. (2000b). Tranzicija, tržište i privatizacija. Ekonomski anali, Ekonomski fakultet u Beogradu, pp. 237-259. 